\title{
Evaluation of Auditors' Professional Skills in Local Auditing Firms in Hanoi
}

\author{
Thi Hanh Duyen NGUYEN ${ }^{1}$, Van Luyen LE$^{2}$, Nguyen Van HAU ${ }^{3}$, Duc Tai DO ${ }^{4}$, Nguyen Thi Thu THAO
}

Received: July 03, 2020 Revised: July 25, 2020 Accepted: August 10, 2020

\begin{abstract}
In recent years, the quality of auditing human resources in domestic auditing firms in Hanoi has certain limitations in which professional skills of auditors have not been given adequate attention. The number of customers at local auditing firms is forecast to increase gradually. Therefore, the quantity and quality of auditors need to be improved to meet requirements of the workload. Data for this research were collected through surveying 120 customers of domestic auditing firms in Hanoi on the 5-point Likert scale. Based on the collected data, we employ both qualitative and quantitative methodology along with some tools such as descriptive statistics, Cronbach's Alpha, T-test and ANOVA to analysis, evaluate and measure the professional skills of auditors in local auditing firms in Hanoi. The results show that the professional skills of auditors in auditing firms include 17 attributes. The majority of respondents show appreciation for the professionalism and professional competence of auditors, while, they think that critical thinking skills and creative thinking skills are still limited and need to be improved. These findings, not only help auditors to improve themselves, but also provide solutions for managers of domestic auditing firms in Hanoi to enhance quality of audited human resources.
\end{abstract}

Keywords: Auditors, Professional Skills, Auditing Firms, Vietnam

JEL Classification Code: M42, J24, O15

\section{Introduction}

Auditing firms, including local auditing firms, are an essential and indispensable part of the economic activities. The independent auditing service provides users with the audit results, which are about whether an understanding of the given financial information by customers is on the basis of the prescribed principles and standards and whether such

${ }^{1}$ First Author. Lecturer, Economics Department, Vinh University, Vietnam. Email: duyenktdhv@gmail.com

${ }^{2}$ Associate Professor, Banking Academy, Vietnam.

Email: luyenlv@hvnh.edu.vn

${ }^{3}$ Corresponding Author. Lecturer, Finance and Accounting 1 Department, Posts and Telecommunications Institute of Technology,

Vietnam [Postal Address: Km. 10, Nguyen Trai Road, Ha Dong District, Hanoi City, 113000, Vietnam] Email: haunv@ptit.edu.vn

${ }^{4}$ Lecturer, Department of Accounting, University of Labor and Social

Affairs, Vietnam. Email: taiketoanquocte@gmail.com

${ }^{5}$ Lecturer, Department of Accounting, University of Labor and Social

Affairs, Vietnam. Email: thaontt9789@gmail.com

(c) Copyright: The Author(s)

This is an Open Access article distributed under the terms of the Creative Commons Attribution Non-Commercial License (https://creativecommons.org/licenses/by-nc/4.0/) which permits unrestricted non-commercial use, distribution, and reproduction in any medium, provided the original work is properly cited. information is honest and reasonable. Independent audit is indispensable in economic activities in a market economy with the State's management. Audit increases the confidence of financial information and contributes to the health of economic relations. Based on the audit results, users of the audited financial statements have objective and accurate information to properly assess the financial situation as well as the business results of enterprises, which is the basis for their economic decisions. In addition to the main objective of giving opinions on financial statements, auditors through the audit process can also make recommendations to help businesses improve their control system and financial management efficiency in particular and business activities in general.

The audit industry has a great influence on many subjects, not only for the businesses that are inspected, but also for investors who are interested in the financial situation of that enterprise. The auditor's report is one of the most reliable documents for external users such as investors and is a legal basis to determine the responsibilities and obligations of enterprises to state agencies. On the other hand, auditors must perform tasks such as: (i) verify the honesty and ensure the legality of financial statements based on specific evidence; 
(ii) evaluate and comment on the investigated results after having sufficient evidence relating to the financial statements; and (iii) advise the management team by pointing out errors in financial statements and proposing corrective measures.

Up to now, there are about 160 independent auditing firms in Vietnam, including four well-known global auditing groups - the Big 4 (KPMG, PricewaterhouseCoopers, Ernst \& Young and Deloitte) (Vietnam Association of Certified Public Accountants-VACPA, 2019). Occupational skills are needed, not only to seek employment, but also to be promoted in the organization through developing personal potential and contributing to the organization's strategic direction under certain conditions, based on smooth integration between hard and soft skills. The development of career skills is also considered in an open relationship (Doan \& Le, 2017).

Auditors' professional competence as well as professional ethics have been increasingly enhanced, but there is still a considerable gap with other developed countries in the world (Pham, 2009). In addition, the professional skills of auditors in domestic auditing firms have limitations compared to foreign-invested auditing firms. From the above reasons, research on assessing occupational skills of auditors in domestic auditing firms in Hanoi is necessary and meaningful in both theory and practice.

\section{Literature Review}

The concept of occupational competence has been discussed by scientists, competence as a basic feature of job performance (McClelland, 1973). Boyatzis (1982) suggested that the professional ability manifests the characteristics of individuals related to performing work effectively. The experts asserted that characteristics of an individual's professional competence include three basic criteria: knowledge, skills, and attitudes.

Knowledge is presented on three levels: (i) general knowledge, (ii) industry knowledge, and (iii) specialized knowledge (Le \& Nguyen, 2012). Skills are factors that can develop, are not innate, and are manifested through expression (Katz, 1974). Skills are the ability to apply the knowledge accumulated during learning or experience to accomplish specific tasks, turning knowledge into action (Cheetham \& Chivers, 1998). Employee's career skills are divided into specific groups: Communication, foreign language, professional, problem-solving, management, awareness and leadership. Attitude is the expression or behavior of an individual at work, and that person's perception of the role and responsibility of the job.

James (2003) argues that career skills are ways to describe the abilities or competencies a person can bring to the organization he or she works for. Occupational skills are essential skills, not only to get a job, but also to advance in the organization through promoting personal potential and contributing to the organization's strategic direction (Hoang,
2012). Occupational skills are the ability to skillfully apply knowledge and techniques, new technologies in the production labor process; at the same time, it is the ability to flexibly adapt in all circumstances, to the relentless changes of the living environment and living conditions for creative labor. Occupational skills include general skills applied to occupations (soft skills) and occupational-specific skills (hard skills) (Doan \& Le, 2017).

Andrews and Higson (2008); Graham et al. (2008); Lievens and Sackett (2012); Nickson et al. (2012) refers to soft skills of employees. Finch et al. (2013) mentioned four types of soft skills: communication skills, active listening skills, professional skills and teamwork skills. Wellman (2010) and Reid and Anderson (2012) discuss employee problemsolving skills. This skill requires the ability to judge, analyze and synthesize, relating to intelligence. Problem-solving skills include critical thinking skills, creative thinking skills, leadership skills, and adaptability (Reid \& Anderson, 2012).

Professional knowledge requirements for employees has been treated by Huang and Lin (2011); Laker and Powell (2011). Professional knowledge includes professional skills, career skills, and knowledge of computers, which are important criteria of employees (Huang \& Lin, 2011; Laker \& Powell, 2011). Le and Nguyen (2020) used primary and secondary data collected from 2018 to 2019 . The results from the interview survey showed that audit firms were aware of the advantages of adopting RBAA. However, RBAA is practiced to a moderate extent by audit firms in Vietnam. The Big 4 audit firms use RBAA more systematically than non-Big 4 audit firms. The results indicated that there were six factors influencing RBAA adoption: auditor's ability, technological development, audit fees, auditors' motivation, audit time, and client's risk

Nguyen et al. (2020) conducted two types of data collections - direct and on survey - analyzed using a factor analysis and comparing means approaches to illustrate the potential IT audit quality factors and identify differences between two groups of auditors. The results show that independence and accounting knowledge and audit skills are the most important factors. Nguyen and Nguyen (2020) collected data was processed by statistical software SPSS, version 23, and Mann-Whitney U test was used to analyze the results of the audit expectation gap between the auditor group and the users of audit report group and between the student group and users of audit report group. The results showed that there exists an expectation gap in the responsibility of auditors for detection of all frauds, errors and protection enterprise's assets.

Researching about professional skills of the auditors, Pham (2009) stated that, in addition to the required professional competence to meet the requirements of auditing, auditors need the following skills: proficiency in using facilities and adapting conditions in service of audit; self-organizing skills, assessing the appropriateness 
of the work need to be done in the audit process; group skill; problem-detecting and solving skills; behavior skills, communication, discussion of issues; information collection skills; oral and written presentation skills; skills to apply professional knowledge and professional standards to audit work; analytical skills and logical thinking; career judgment skills; skills on ability to control emotions, and career sensitivity. These skills are factors that contribute to the quality and economic aspects of auditing. In addition, when auditors perform the audit, they must use various basic audit skills in which communication skills are considered important because good communication skill helps auditors attract and maintain relationships with their customers, obtain audit evidence and persuade customers to listen to the audit results (Nguyen, 2011).

Employee's occupational skills can be popularly evaluated from various perspectives - employers, employees and customers. However, when researching professional skills of auditors, most studies used information from customers' survey, because employees try to improve their capacity in order to improve their assigned task quality, from which customers will be satisfied with the service they provide. Therefore, customer's assessment of the auditor's professional skills is more accurate than other subjects' assessment. Inheriting the above studies and through discussions with experts, we summarize skills of auditors in Table 1 as follows:

Table 1: The professional skills of auditors

\begin{tabular}{|c|c|c|}
\hline Code & cale & ces \\
\hline PSA1 & $\begin{array}{l}\text { Communication } \\
\text { skill }\end{array}$ & $\begin{array}{l}\text { Katz (1974), James (2003), Andrews \& Higson (2008); Graham et al. (2008); Pham (2009), } \\
\text { Nguyen (2011), Lievens \& Sackett (2012); Nickson et al. (2012), Finch et al. (2013), Doan \& } \\
\text { Le (2017) }\end{array}$ \\
\hline PSA2 & ctiv & $\begin{array}{l}\text { Katz (1974), Cheetham \& Chivers (1998), James (2003), Andrews \& Higson (2008); Graham } \\
\text { et al. (2008); Lievens \& Sackett (2012); Nickson et al. (2012), Finch \& et al. (2013), Doan \& Le } \\
(2017)\end{array}$ \\
\hline PSA3 & ill & Katz (1974), Cheetham \& Chivers (1998), James (2003), Finch et al. (2013), Doan \& Le (2017) \\
\hline PSA4 & Tear & $\begin{array}{l}\text { 74), Cheetham \& Chivers (1998), James (2003), Andrews \& Higson (2008); Graham } \\
\text { Le8); Pham (2009), Lievens \& Sackett (2012); Nickson et al. (2012), Finch et al. (2013), } \\
\text { Le (2017) }\end{array}$ \\
\hline PSA5 & Criti & $\begin{array}{l}\text { Katz (1974), Cheetham \& Chivers (1998), James (2003), Andrews \& Higson (2008); Graham } \\
\text { et al. (2008); Pham (2009), Lievens \& Sackett (2012); Nickson et al. (2012), Reid \& Anderson } \\
\text { (2012), Doan \& Le (2017) }\end{array}$ \\
\hline PSA6 & Crea & $\begin{array}{l}\text { Katz (1974), Cheetham \& Chivers (1998), James (2003), Andrews \& Higson (2008); Graham } \\
\text { et al. (2008); Lievens \& Sackett (2012); Nickson et al. (2012), Reid \& Anderson (2012), Doan } \\
\text { \& Le ( 2017) }\end{array}$ \\
\hline PSA7 & Profession & $\begin{array}{l}\text { ), Huang \& Lin (2011); Laker \& Powell (2011), Le \& Nguyen (2012), Cheetham \& } \\
\text { 98), James (2003), Doan \& Le (2017) }\end{array}$ \\
\hline PSA8 & $y$ & $\begin{array}{l}\text { \& Higson }(200 \\
\text { al. }(2012) \text {, Do }\end{array}$ \\
\hline PSA9 & $\begin{array}{l}\text { Com } \\
\text { Profi }\end{array}$ & $\begin{array}{l}\text { (2003), Andrews \& Higson (2008); Graham et } \\
\text { aker \& Powell (2011), Lievens \& Sackett (2012); }\end{array}$ \\
\hline SA10 & Num & $\begin{array}{l}\text { Katz (1974), Cheetham \& Chivers (1998), James (2003), Andrews \& Higson (2008); Graham } \\
\text { et al. (2008); Lievens \& Sackett (2012); Nickson et al. (2012), Doan\& Le (2017) }\end{array}$ \\
\hline PSA11 & sis & $\begin{array}{l}\text {, Cheetham \& Chivers (1998), James (2003), Andrews \& Higson (2008); Graham } \\
\text {; Pham (2009), Lievens \& Sackett (2012); Nickson et al. (2012); Doan \& Le (2017) }\end{array}$ \\
\hline PSA12 & $\begin{array}{l}\text { Time } \\
\text { skill }\end{array}$ & $\begin{array}{l}\text { 1998), James (2003), Andre } \\
\text { 12); Nickson et al. (2012), }\end{array}$ \\
\hline PSA13 & Emo & s (2003), Pham (2009), Doar \\
\hline 114 & $\begin{array}{l}\text { Occl } \\
\text { intui }\end{array}$ & $(2017)$ \\
\hline 15 & Inter & $\begin{array}{l}\text { s \& Higson }(200 \\
\text { an\& Le (2017) }\end{array}$ \\
\hline PSA16 & $\begin{array}{l}\text { Inter } \\
\text { Pers } \\
\end{array}$ & $\begin{array}{l}\text { Katz (1974), Cheetham \& Chivers (1998), James (2003), Andrews \& Higson (2008); Graham } \\
\text { et al. (2008); Pham (2009), Lievens \& Sackett (2012); Nickson et al. (2012); Doan \& Le (2017) }\end{array}$ \\
\hline 17 & English proficiency & $\begin{array}{l}\text { (1998), James (2003), Andrews \& Higson (2008); Graham } \\
012) ; \text { Nickson et al. (2012), Doan \& Le (2017) }\end{array}$ \\
\hline
\end{tabular}




\section{Research Methodology}

\subsection{Research Sample}

The research sample is an important factor that determines the success of a quantitative study. Generally, there are two methods to choose: random sampling and haphazard sampling. The random sampling is more widely used and brings more objective results. In this paper, we randomly select the firms that are customers of local auditing firms in Hanoi. We sent over 200 surveys forms to chief accountant of businesses and within two months we collected 150 surveys forms. After removing unqualified survey forms, the official sample included 120 firms that are customers of local auditing firms in Hanoi.

\subsection{Analysis Approach}

Items are measured based on the 5-point Likert scale, from 1 'Strongly disagree' to 5 'Strongly agree'. To test the attributes, we use SPSS 22 software to perform the following analysis: descriptive statistics, reliability test of scale by Cronbach's Alpha scale, T-Test and ANOVA.

\section{Results}

\subsection{Descriptive Statistics}

Respondents were categorized by gender, work experience, and area of operations (see Table 2). Table 2 shows that among 120 respondents, $25.8 \%$ were male, the remaining 89 were female $(74.2 \%)$. Of these, $51.7 \%$ of the participants have work experience less than five years, and
$48.3 \%$ over five years. Of the total 120 respondents, 38 $(31.7 \%)$ are working at industrial production enterprises, 51 $(42.5 \%)$ are working at trade and services enterprises, and 31 $(25.8 \%)$ are working at construction enterprises.

Table 3 reveals that respondents agree with the dependent variables of 'The professional skills of auditors', where seventeen (17) attributes from JC1 to JC17 were quite high with an average of 3.74 in the 5-point Likert scale. All 17 attributes were rated at an average of 3.55 or higher.

\subsection{Results of Quality Scale Analysis}

The professional skills of auditors have been measured by Cronbach's Alpha, with a coefficient of 0.886 . Results of testing Cronbach's Alpha of attributes are presented in Table 4. Data in Table 4 also illustrate that attributes of the dependent variables having a Cronbach's Alpha coefficient higher than 0.6, were less than the common Cronbach's Alpha coefficient; the correlation coefficient of all attributes was greater than 0.3 , so all the attributes of the dependent variables were viewed as statistically significant (Hair et al, 2009; Hoang \& Chu, 2008).

\subsection{Independent T-test}

A work experience evaluation of the professional skills of auditors, is presented in Table 5. Data in Table 5 show that Sig Levene's Test $=0.815$, bigger than 0.05 ; the variance between the two less 5 years and over 5 years is not different. Moreover, Sig value T-Test $=0.575>0.05$. This means there is statistically no significant difference in the level of the professional skills of auditors, between the two work experiences of less five years and over five years (Hoang \& Chu, 2008; Hair et al. 2009).

Table 2: Respondents by gender, work experience and area of operations

\begin{tabular}{|l|c|c|c|}
\hline & Frequency & Percent & Cumulative Percent \\
\hline Genders & 31 & 25.8 & 25.8 \\
\hline Male & 89 & 74.2 & 100.0 \\
\hline Female & \multicolumn{5}{|l|}{} \\
\hline Work experience & 62 & 51.7 & 51.7 \\
\hline Less 5 years & 58 & 48.3 & 100.0 \\
\hline Over 5 years & \multicolumn{3}{|l|}{} \\
\hline Area of operations & 38 & 31.7 & 31.7 \\
\hline Industrial production & 51 & 42.5 & 100.0 \\
\hline Trade and services & 31 & 25.8 & \\
\hline Construction & 120 & 100.0 & \\
\hline Total & & & \\
\hline
\end{tabular}


Table 3: Descriptive Analysis of Attributes of the professional skills of auditors

\begin{tabular}{|l|c|c|c|c|c|}
\hline & $\mathbf{N}$ & Minimum & Maximum & Mean & Std. Deviation \\
\hline PSA1 & 120 & 2.00 & 5.00 & 3.78 & .641 \\
\hline PSA2 & 120 & 2.00 & 5.00 & 3.81 & .584 \\
\hline PSA3 & 120 & 2.00 & 5.00 & 3.79 & .755 \\
\hline PSA4 & 120 & 2.00 & 5.00 & 3.76 & .733 \\
\hline PSA5 & 120 & 2.00 & 5.00 & 3.62 & .663 \\
\hline PSA6 & 120 & 2.00 & 5.00 & 3.55 & .708 \\
\hline PSA7 & 120 & 2.00 & 5.00 & 3.88 & .728 \\
\hline PSA8 & 120 & 2.00 & 5.00 & 3.93 & .632 \\
\hline PSA9 & 120 & 2.00 & 5.00 & 3.86 & .702 \\
\hline PSA10 & 120 & 2.00 & 5.00 & 3.91 & .635 \\
\hline PSA11 & 120 & 2.00 & 5.00 & 3.83 & .748 \\
\hline PSA12 & 120 & 2.00 & 5.00 & 3.65 & .752 \\
\hline PSA13 & 120 & 2.00 & 5.00 & 3.78 & .739 \\
\hline PSA14 & 120 & 2.00 & 5.00 & 3.60 & .726 \\
\hline PSA15 & 120 & 2.00 & 5.00 & 3.62 & .747 \\
\hline PSA16 & 120 & 2.00 & 5.00 & 3.63 & .841 \\
\hline PSA17 & 120 & 2.00 & 5.00 & 3.68 & .820 \\
\hline Valid N (listwise) & 120 & & & 3.74 & \\
\hline
\end{tabular}

Table 4: Results of Cronbach's Alpha Testing

\begin{tabular}{|l|c|c|c|c|}
\hline & $\begin{array}{c}\text { Scale Mean if Item } \\
\text { Deleted }\end{array}$ & $\begin{array}{c}\text { Scale Variance if Item } \\
\text { Deleted }\end{array}$ & $\begin{array}{c}\text { Corrected Item-Total } \\
\text { Correlation }\end{array}$ & $\begin{array}{c}\text { Cronbach's Alpha if Item } \\
\text { Deleted }\end{array}$ \\
\hline The professional skills of auditors (PSA): Cronbach's Alpha: .959 & \multicolumn{2}{|c|}{} \\
\hline PSA1 & 59.88 & 82.474 & .643 & .959 \\
\hline PSA2 & 59.85 & 82.918 & .669 & .958 \\
\hline PSA3 & 59.87 & 80.738 & .669 & .958 \\
\hline PSA4 & 59.90 & 80.595 & .702 & .958 \\
\hline PSA5 & 60.04 & 81.486 & .706 & .958 \\
\hline PSA6 & 60.11 & 80.131 & .769 & .957 \\
\hline PSA7 & 59.78 & 80.104 & .747 & .957 \\
\hline PSA8 & 59.73 & 81.243 & .767 & .957 \\
\hline PSA9 & 59.80 & 80.363 & .757 & .957 \\
\hline PSA10 & 59.75 & 81.164 & .770 & .957 \\
\hline PSA11 & 59.83 & 79.440 & .778 & .957 \\
\hline PSA12 & 60.01 & 79.353 & .781 & .956 \\
\hline PSA13 & 59.88 & 79.146 & .813 & .956 \\
\hline PSA14 & 60.06 & 79.686 & .784 & .956 \\
\hline PSA15 & 60.04 & 79.956 & .739 & .957 \\
\hline PSA16 & 60.03 & 77.797 & .801 & .956 \\
\hline PSA17 & 59.98 & 77.840 & .820 & .956 \\
\hline
\end{tabular}


Table 5: Differences of the professional skills of auditors - Independent Samples Test

\begin{tabular}{|c|c|c|c|c|c|c|c|c|c|c|}
\hline & \multicolumn{2}{|c|}{$\begin{array}{l}\text { Levene's Test } \\
\text { for Equality of } \\
\text { Variances }\end{array}$} & \multicolumn{7}{|c|}{ t-test for Equality of Means } \\
\hline & & \multirow[t]{2}{*}{$\mathbf{F}$} & \multirow[t]{2}{*}{ Sig. } & \multirow[t]{2}{*}{$t$} & \multirow[t]{2}{*}{ df } & \multirow[t]{2}{*}{ Sig. } & \multirow[t]{2}{*}{$\begin{array}{c}\text { Mean } \\
\text { Difference }\end{array}$} & \multirow[t]{2}{*}{$\begin{array}{l}\text { Std. Error } \\
\text { Difference }\end{array}$} & \multicolumn{2}{|c|}{$\begin{array}{l}95 \% \text { Confidence } \\
\text { Interval of the } \\
\text { Difference }\end{array}$} \\
\hline & & & & & & & & & Lower & Upper \\
\hline \multirow{2}{*}{ PSA } & $\begin{array}{l}\text { Equal } \\
\text { variances } \\
\text { assumed }\end{array}$ & .055 & .815 & -.588 & 118 & .557 & -.04999 & .08498 & -.21827 & .11829 \\
\hline & $\begin{array}{l}\text { Equal } \\
\text { variances not } \\
\text { assumed }\end{array}$ & & & -.589 & 117.732 & .557 & -.04999 & .08492 & -.21817 & 11819 \\
\hline
\end{tabular}

Table 6: Test of Homogeneity of Variances

\begin{tabular}{|c|c|c|c|}
\hline Levene Statistic & df1 & df2 & Sig. \\
\hline .455 & 2 & 117 & .636 \\
\hline
\end{tabular}

Table 7: ANOVA

\begin{tabular}{|l|c|c|c|c|c|}
\hline & Sum of Squares & Df & Mean Square & F & Sig. \\
\hline Between Groups & 1.172 & 2 & .586 & 2.806 & .065 \\
\hline Within Groups & 24.438 & 117 & .209 & & \\
\hline Total & 25.611 & 119 & & & \\
\hline
\end{tabular}

\subsection{ANOVA Analysis}

ANOVA testing helps us compare the results of the evaluation, of the professional skills of auditors, including industrial production enterprises, trade and services enterprises and construction enterprises. Table 6 shows the Sig. Levene Statistic of $0.636>0.05$. Thus, the hypothesis of homogeneity variation among the variable value groups (different area of operations) has not been violated (Hoang $\&$ Chu, 2008; Hair et al. 2009).

Table 7 illustrates that Sig. $=0.065>0.05$. This mean there is not a statistically significant difference in the level of the professional skills of auditors for the three mentioned groups of area of operations.

\section{Discussion and Implications}

\subsection{Communication Skill}

Communication skill is part of an auditor's daily life and of their job such as discussing, exchanging ideas with colleagues in the department and other departments in the enterprise; clearly conveying thoughts, ideas, and suggestions in meetings; negotiating and persuading customers about findings in the process of financial statements auditing; presenting in-depth issues so that the Board of Directors at customers side can understand the issues that need to be discussed and resolved with the auditor. Communication skill is highly appreciated by the management board of auditing firms when recruiting employees and by customers. Therefore, auditors should enhance this skill by training themselves in interpreting coherently and comprehensively.

\subsection{Active Listening Skill}

The ability to listen to others is one of the essential skills of an auditor. Auditors listen to the instruction of the Board of Directors, of the audit team leader, listen to the discussion of members in the audit team; listen to their customers. Several auditors recommend that $75 \%$ to $80 \%$ of the time is listening and should only speak in $20 \%$ to $25 \%$ of a conversation. To improve this skill, auditors need to actively listen to care, to understand and to learn. 


\subsection{Professional Skill}

The method and the way that auditors handle the large amount of information provided and present it in a suitable and scientific way to easy to understand with neatly aligned is one of the manifestations of professionalism in audit job. The higher the computer skill is, the more professional auditors will be.

\subsection{Teamwork Skill}

Auditors need to be able to work independently and to work in a team due to the nature of the auditing with an exact process and several steps to be taken. In enterprises providing audit services, audit groups are established including the team leader and members. In a group, the leader will lead the team to ensure the task progress, at the same time provide solutions to emerging problems and discuss together to find out the optimal solution. The solidarity and good coordination of a team will help the whole team to complete the job successfully. Teamwork skill is further improved when auditors accompany each other and supporting each other. In addition, leadership ability of the team leader has a positive influence on the teamwork skill of auditors.

\subsection{Critical Thinking}

Critical thinking skill is the ability to think clearly and make proper arguments about believes or their work. It is the ability to think independently and think reflectively. Auditors apply critical thinking skill to solve problems in a systematic way, consider customers' perspective in the reasoning and soundness, analyze and assess information and events in an audit objectively.

\subsection{Creative Thinking}

Along with professional competence and analytical skill, the creative thinking of auditors is always applied in the work of auditors. Because the nature of an auditor is to detect errors and frauds in financial and accounting activities and to cooperate with many auditing units in different situations. Logical thinking combined with communication skill will build trust from customers (customers are available to report and provide their company's data when they have confidence) and from a colleague.

\subsection{Professional Ability}

Auditors must constantly work with completely different new data from different customers, and they must also familiarize themselves with the changing culture and working environment of businesses. Therefore, knowledge of accounting and auditing is one of the very important skills in auditing work. Thus, when determining long-term commitment to the audit profession, auditors have had to cultivate themselves with basic professional skills. In addition to knowledge of accounting and auditing, auditors need to improve their knowledge of specialized laws, finance, banking and taxation, etc.

\subsection{Self-Organizing Skills}

Auditors organize the assigned work, determine what needs to be done, and assign auditing team members to undertake the tasks. In the process of doing the job, to know how to create horizontal and vertical relationships within the enterprise.

\subsection{Computer Proficiency}

A laptop is one of the devices attached to the auditor. Good computer skill, not only helps auditors save time, but also helps them reduce work pressure. Auditors will use Excel to calculate and prepare reports; use Word in preparing presentation, formatting financial statements and audit reports; use PowerPoint to present in meetings with customers, etc. Auditors with computer proficiency will calmly handle dozens of WorkSheet in Excel with calculation functions, will align data cells and then present with clear text.

\subsection{Numerical Skill}

Numerical skill is not only used to calculate indicators, to check the accuracy of numbers in accounting reports, but also to find out the relationships between numbers and the sensitivity of those numbers. For example, company A's revenue report shows its revenue in the last two years. With numerical skill, the auditor can immediately compare the revenue of those two years. Numerical skill helps practicing with exercises in accounting, auditing, finance and statistics; reading, checking and calculating the targets from the financial statements of listed companies published on the website can enhance this skill of an auditor.

\subsection{Logical Analysis Skill}

Analytical thinking skill is one of the common skills used in professional fields in general and in auditing field in particular. When using logical analysis skill, auditors can explain the fluctuations of data on the financial statements, the impact of the adjustment journal on the financial statements of customers. Logical analysis is definitely improved according to the number of working experience years of auditors. Auditing industry requires scientific and 
logical qualities, each problem will have different solutions and lead to completely different results. The logical thinking ability helps auditors arrange the work to be done scientifically, and find out the strengths and weaknesses of each solution to provide the best adjustment.

\subsection{Time Management Skill}

The characteristics of an auditing job include high work pressure, precise deadlines, fixed total working time, etc. Therefore, time management skill helps auditors to ensure the progress of their work, improve their reliability to the Board of Directors, colleagues and customers; maintain a work-life balance effectively. Time management skill is that auditors know how to divide their time appropriately, constantly reset their priorities in the list, use support tools like calendars, colored marker folders, applications and software on your computer. Time management skill can be improved by self - studying and continuously practicing. The actual working time of auditors in each client is different, depending on the nature and requirements of each customer. If the customer has a large amount of information to handle with complex nature, large scale and short time request, the auditors must work overtime and the working time can be in a whole week to ensure the completion of the schedule. Therefore, good time management helps auditors not get stressed when performing the work.

\subsection{Emotional Quotient}

Auditors must always adhere to professional ethical standards, thereby improving their emotional intelligence. Auditors promote honesty, have a certain degree of empathy with colleagues and customers, maintain a calm attitude, a fair look, and do audits correctly with full procedures.

\subsection{Occupational Intuition}

Many experts believe that, in order to carry out a high quality audit, the auditor must demonstrate his / her professional intuition and be able to ask the right questions in an objective and constructive manner. Professional intuition is useful when auditors design and fulfill audit commitments; check and review the chain of audit evidence to ensure authentication, etc. When auditors have more experience, the intuition of professional will certainly improve.

\subsection{Interactive Skill}

Interactive skill is needed both in daily life and in working environment. There is a difference between interactive and communication skills. Interaction skill is the ability to express sympathy of auditors. Interactive skill helps auditors better understand the characteristics of customers and affirm their expertise.

\subsection{Interpretation and Persuasion Skill}

The basic function of an audit is to verify and express opinions. When auditors express their opinions with high interpretation and persuasion skills, they will persuade customers to listen and agree with their statements, thereby improving customers' trust then customers will continue to use the service. Auditors need to improve their interpretive and persuasive skills, which is one of the mandatory skills, and avoid implementing this instinctively.

\subsection{English Proficiency}

The Ministry of Finance has signed a document of the roadmap to apply international financial reporting standards (IFRSs) in Vietnam. In addition, there are many accounting and auditing documents in English that auditors must research to improve their qualifications. Therefore, English skill is important to auditors, especially to foreign-invested enterprises with foreign employees. Improving English skills is one of the things that auditors need to do, including paying attention to communicating English and English for accounting and auditing; use English properly, avoid speaking Vietnamese alternating with English.

\section{Conclusion}

In the process of performing the audit, situations where this task is performed can vary greatly. In these difficult situations, beside professional and adaptive skills, the job skills of the auditor are expected at a high level. Auditors select short-term courses and training to improve professional skills such as certificates of international accounting/auditing (CFA or ACCA, AFMA). The diversity of the working environment has provided auditors with an open career opportunity. In the process of working, they can expand their relationships with senior executives of companies and get exposure to various corporate cultures, which gives them knowledge and interactive experience, so it is easy to be promoted in their career. However, to achieve that success, auditors need to continuously build and improve their skills. They must be self-aware and take steps to cultivate their skills, then the support of agencies and colleagues will come after.

\section{References}

Andrews, J., \& Higson, H. (2008). Graduate employability, soft skills versus hard business knowledge: A European study. Higher Education in Europe, 33(4), 411-422. 
Boyatzis, R. E. (1982). The competent manager: A model for effective performance. Hoboken, NJ: John Wiley \& Sons.

Cheetham, G., \& Chivers, G. (1998). The reflective (and competent) practitioners: a model of professional competence which seeks to harmonise the reflective practitioner and competence - based approaches. Journal of European Industrial Training, 22(7), 267-276.

Doan, H. D., \& Le, T. T. M. (2017). Study on influence of employability skill in university on relationship with enterprises. Journal Scientific of Van Lang University, 4/2017, 48-54. [Vietnamese]

Finch, D. J., Hamilton, L. K., Baldwin. R., \& Zehner, M. (2013). An exploratory study of factors affecting undergraduate employability. Education and Training, 55(7), 681-704.

Graham, A. S., Willett, C., \& Hampton, M. (2008). What not to write: an intervention in written communication skills for accounting students. International journal of Management Education, 8(2), 67-74. DOI:10.3794/ijme.82.265.

Hair, J. F., Black, W. C., Babin, B. J., \& Anderson, R. E. (2009). Multivariate Data Analysis (7th ed.). Upper Saddle River, NJ: Prentice Hall International.

Hoang, T., \& Chu, N. M. N. (2008). Analysis of research data with SPSS. Hanoi, Vietnam: Hong Duc Publishing House. [Vietnamese]

Hoang, T. T. (2012). Career development strategies for UEF students. Seminar on skills and attitude training - creating a solid corridor for students to come to life. Ho Chi Minh City, Vietnam: University of Economics Ho Chi Minh City.

Huang, Y., \& Lin, C.(2011). Management Trainee CoreCompetencies in the Hospitality Industry: Differences between Managers and Scholars. Journal of Human Resources in Hospitality \& Tourism, 10(1), 1-13. DOI: 10.1080/15332845.2010.500166.

Katz, R. L. (1974). Skills of an effective administrator. Cambridge, MA: Harvard Business Press.

James, W. B. (2003). Marketing Job Skills: Educator, Practitioner, and Student Perceptions. Proceeding of the Academy of Marketing Studies, 8(1), 7-14.

Laker, D. R., \& Powell, J. L. (2011). The differences between hard and soft skills and the relative impact on training transfer.
Human Resource Development Quarterly, 22(1), 111-122. https://doi.org/10.1002/hrdq.20063.

Le, Q. \& Nguyen, Q. K. (2012). Assessing the capacity of Vietnamese small business executives through ASK model. Vietnam University Journal of Science, 28, 29-35. [Vietnamese]

Le, T. T., \& Nguyen, T. M. A (2020). The Adoption of Risk Based Audit Approach in the Independent Audit Firms: A Study of Case of Vietnam. Journal of Asian Finance, Economics and Business, 7(2), 89-97. https://doi.org/10.13106/jafeb.2020. vol7.no2.89.

Lievens, F., \& Sackett, P. R. (2012). The validity of interpersonal skills assessment via situational judgment tests for predicting academic success and job performance. Journal of Applied Psychology, 97(2), 460-468. Doi: 10.1037/a0025741.

McClelland, D. C. (1973). Testing for competence rather than for intelligence. American Psychologist, 28(1), 1-14.

Nguyen, A, H., Ha, H. H., \& Nguyen, S. L. (2020). Determinants of Information Technology Audit Quality: Evidence from Vietnam. Journal of Asian Finance, Economics and Business, 7(4), 41-50. https://doi.org/10.13106/jafeb.2020.vol7.no4.41.

Nguyen, H. T., \& Nguyen, A. H. (2020). Audit Expectation Gap: Empirical Evidence from Vietnam. Journal of Asian Finance, Economics and Business, 7(5), 51-60. https://doi.org/10.13106/ jafeb.2020.vol7.no5.051.

Nguyen, T. H. M. (2011). 5 communication principles required for an auditor. Journal of Trade, 16/2011, 16-17. [Vietnamese]

Nickson, D., Warhurst, C., Commander, J., Hurrell, S. A., \& Cullen, A. M. (2012). Soft skills and employability: Evidence from UK retail. Economic and Industrial Democracy, 33(1), 65-84. doi. org/10.1177/0143831X11427589.

Pham, T. H. (2009). Vietnamese auditors in terms of integration and development: Current situation and solutions. Journal of Auditing, 4, 19-23. [Vietnamese]

Reid, J. R., \& Anderson, P. R. (2012). Critical Thinking in the Business Classroom. Journal of Education for Business, 87(1), 52-59. doi.org/10.1080/08832323.2011.557103.

Wellman, N. (2010). The employability attributes required of new marketing graduates. Marketing Intelligence \& Planning, 28(7), 908-930. 